\title{
A history of non-human lives: social weeds ${ }^{1}$
}

\section{Monika Weychert}

(SWPS University of Social Sciences and Humanities)

\begin{abstract}
:
The author analyzes Karolina Grzywnowicz's installation Weeds (2015): a meadow which the artist replanted from two villages in Bieszczady — whose inhabitants had been resettled in 1944-1950 —into a site adjoining a street in Warsaw. The meadow was promptly mowed by the municipal services, and thus became a twofold commemoration. First, it was a deliberately created yet subtle and poetical monument to the displaced people. Second, in a manner unanticipated by the artist, it grew into a symbolic martyrdom memorial of the "green urban anarchists": weeds in other words. The author analyzes the relationships between non-human lives and history, asking whether the marginal history of plants is ever noticed in scientific and social reflection, as well as wondering about the role of plants in commemoration and why they fail as a medium of memory.
\end{abstract}

Key words:

art, history, memory, nature, non-human beings

The work by Karolina Grzywnowicz delves into relationships between non-human lives and history. However, has the peripheral history of plants to which the author draws attention been noted by scientific and social reflection? What role do plants play in the context of commemoration?

The protagonists in this text are apple, pear, plum, and cherry trees, gooseberry and currant bushes, hazels, walnut trees, lindens, cutleaf coneflowers, daffodils, irises, asters, dwarf periwinkles, boxwoods, guelder-roses, common nettles, couch grasses, Alpine docks, centaureas; the reminiscence also features flax dodder and flat-seeded false flax, and there are the rarely encountered flame adonis, shepherd's-needle, summer pheasant's-eye, hedgehog parsley, cowherb, field fennel, staggerweed, corn buttercup, blue pimpernel, common corn-cockle, roundleaf cancerwort, sharpleaf cancerwort, common catchfly, rye brome, yellow star-of-Bethlehem, and field larkspur.

1 This text was written during the seminar held by Anna Zeidler-Janiszewska in 2016-2017 entitled Historical policies versus history and memory - selected case studies. 
The installation entitled Weeds ${ }^{2}$ is a meadow that Grzywnowicz transplanted from two villages in Bieszczady whose inhabitants had been resettled in 1944-1950. Paweł Mościcki wrote about the installation: "the poetic in the project begins from listening into the silent protest of the earth, which compels the abandoned plants to endure and develop, despite political decisions" (Mościcki, nd; no longer accessible). Post-war resettlements were carried out on a tremendous scale. The Recovered Territories were bathed in the mythology of a return to the "cradle of Polishness," to the "bosom of the motherland," a civilization that began with the house of Piast. This was accompanied by special metaphors of Ithaca, Colchis, or Arcadia, where the golden fleece and gardens of paradise awaited the new inhabitants. ${ }^{3}$ Meanwhile, not a thing was heard about the 600,000 people who were deported from Bieszczady, Beskid Niski, Beskid Sądecki, Pogórze Przemyskie, and Roztocze in the course of two resettlement undertakings: "repatriation" of the Ukrainian population to the USSR (1944-1946), which displaced 480,00o people, and Operation Vistula (1947-1950), during which 140,00o were relocated. Grzywnowicz repeats that gesture with respect to plants. Fragments of forgotten gardens travel hundreds of kilometers, from one end of Poland to another. This immediately provokes questions among observers: does it make sense? Will the plants adapt to the new environment? Will they survive? Is it not barbaric? The very questions that should have arisen and been asked in the context of the eviction and forced displacement of Lemkos and Ukrainians in the past. After all, ectozoochory (the dispersal of seeds, spores, and seedlings by animals) is nothing new to plants; on the contrary, it is a strategy of survival and proliferation.

The dwellings and the villages would often be burned down-only the old gardens, fields, and orchards remained. "Plants are an ever-regenerating and permanent testimony to the presence of people in places they had long abandoned. Changes in the structure and chemical composition of the soil go so far as to enable those species to survive even for the next 600 years. Knowledge of the plants helps one find resettled villages, can serve to reconstruct their topography and provides a key to the understanding of that space" (Grzywnowicz, n.d.). The situation is akin to the history of Kupferberg (Miedzianka in Lower Silesia), described by Filip Springer. In a town which disappeared from the surface of the earth after six centuries of affluent existence, the writer looks for traces of life like an archaeologist. What he encounters are plants, once companions of the human beings, now taking their place. The doom of the town is heralded by the disappearance of

2 The project was carried out as part of the "1 na 1 - Mistrz i Uczeń" program by the Association of Creative Initiatives "e" and presented for the first time in autumn 2015 at Zachęta Project Room. Subsequently, the installation moved to the embankment on the Vistula, in the vicinity of the University Library and the Copernicus Science Centre, as part of Bęc Zmiana's series Synchronization. The 2016 edition was devoted to seeking balance in organizing and designing urban and social space. Its core theme was "unsustainable architecture," construed as creating an environment that fulfills dreams of better future.

3 See Nijakowski (2006), Gieba (2017). 
a cherry tree which is swallowed by a fissure caused by the subsidence of a uranium mine (Springer 2011). The process had already been described by Ewa SzelburgZarembina in connection with the Great War:

The house stood on the frontline-the people had to abandon their home. And even though later the storm of war went by and died down, they did not return. Meanwhile, in the deserted garden surrounding the empty dwelling strange things began to happen. [...]

'War!' And thousands of hate-spewing voices followed suit, 'War! War! War!'

Things seethed, and commotion stirred through the Garden from end to end. The ditches, the paths, and the laws were raided by countless packs of weeds, followed by mercenary troops of destruction-wreaking insects, marching in close ranks. [...] As far as the eye could see, across the turf, paths, and squares, weeds-fat and sinewy, sticky and stinging-drove unstoppably towards the flowerbeds and the patches. In a moment, they would descend on the less numerous residents of the Garden and crush them with the mass of their bodies, stifle them in a deadly embrace. Yet here they halted, as if rooted to the spot: just in front of them [...] there appeared the King of the Garden, Marcin, and a little, red girl. [...] Marcin and Iruchna sat down on the porch under the eaves of the garden house and, cuddled together, looked with a smile on the frolicking frogs, on the birds washing dust off their tired wings, on flowers, vegetables and trees drinking in the gifts of the skies in the serenity of heart rejoicing with victory. (Szelburg-Zarembina 1972, 251, 252, 336)

In this excerpt from the short story Ogród króla Marcina (King Martin's Garden) the mixing of ornamental plants with weeds means prolongation of war and a hostile invasion. Only people are capable of putting a stop to it and yet again becoming guarantors of security in the garden. A similar description may be found in Frances Hodgson Burnett's The Secret Garden, published a few years earlier. There is no place for weeds there, the baleful other of gardens, though "common" plants do appear. If indeed Marx vies with Darwin for intellectual leadership (Domańska 2010), it is worthwhile to note that in the English garden the "class division" between plants is lifted. "The seeds Dickon and Mary had planted grew as if fairies had tended them. Satiny poppies of all tints danced in the breeze by the score, gaily defying flowers which had lived in the garden for years and which it might be confessed seemed rather to wonder how such new people had got there" (Burnett 1911, 296). The protagonists of that pantheistic novel for children which had been inspired by Christian Science, Martha and Dickon Sowerby, are representatives of a lower class-the servants-and it is they who bring new seeds to enrich the aristocratic flowerbeds. In a hardly noticeable way, they change the social arrangements. Interestingly enough, Burnett and her religious community would have probably subscribed to some of Marx's assertions:

Labour is, in the first place, a process in which both man and Nature participate, and in which man of his own accord starts, regulates, and controls the material re-actions 
between himself and Nature. He opposes himself to Nature as one of her own forces, setting in motion arms and legs, head and hands, the natural forces of his body, in order to appropriate Nature's productions in a form adapted to his own wants. By thus acting on the external world and changing it, he at the same time changes his own nature. (Marx 1932, 197-198)

This is exactly what happened to Mary Lennox and Colin Craven: spoiled, unkind, and physically weak children who thanks to working in the mysterious garden begin to flourish acquiring both physical and moral fortitude. In his now classic text, Neil Smith (1984) engaged in an extensive critique of the notion of nature, questioning the intuitive yet well-established division into "first" and "second" nature. In his opinion, there is no longer any nature one controls and a nature one creates to achieve mastery over the latter. Through human labor and the production of nature at the global scale, human society has placed itself squarely at the center of nature. To wish otherwise is nostalgic. This centrality in nature is what fuels the crazy quest of capital actually to control nature, but the idea of control over nature is a dream. It is the dream dreamt each night by capital and its class, in preparation for the next day's labor, as he wrote. (Smith 1984) Smith is also a pessimist as far as "bourgeois" ecology is concerned, observing that each change gives rise to new markets within capitalism: regulation of greenhouse gas emissions led to trade in permits, while biotechnologies drove large corporations into patent races. Commodification of natural assets and global production of nature have severely affected biodiversity. Nowhere can one find room for the green anarchy of plants that are deemed undesirable in cultivation. The human has become so efficient in their eradication that at present some weeds are either utterly extinct or have been entered into regional red lists of vanishing or extremely threatened species. The meadows where weeds were once to be found have been disappearing as well, though the weeds had been previously eliminated on agricultural meadowland. In Europe today, special programs have been implemented to protect these plants: seed collections are established, conservative cultivation is employed, while "weed gardens" have become something of a fashion.

The form of the work presented in autumn 2015 at the Zachęta Project Room brought Albrecht Dürer's The Great Piece of Turf to mind. In the past, floral motifs used to adorn everything, from dresses and paintings to temples (such as the famed polychromies and frescos in St. Martin's Church in Bamberg, most often referred to as Himmelsgarten, the heavenly garden), with a wealth of symbolism that developed around them (somewhat ambivalent in the case of grasses and herbs-from Christian to pagan). However, the perceptual habits of the contemporary viewer do not permit conducting an iconological analysis of vegetal representations. It is only to be regretted, since they would be able to supply unique knowledge of historical and cultural circumstances which engendered the exploitation and protection of the "Kingdom of Flora." "I love thine bare feet, / For they tread on brittle 
dew, telling a-blind the cornflowers and the corncockle," wrote Bolesław Leśmian (Leśmian, 1920). This is a very interesting example of how the interpretation of usefulness of plants fluctuated. In the poem, corncockles are a pest one can tread on, whereas cornflowers are friendly and beautiful "morsels of blue" in the field. Cornflowers would very often recur as a motif in poetry, always evoking positive associations. Their color also justifies the traits at the connotative core of the words "beauty," "happiness," "love," "faithfulness," "good," "innocence," or "sinlessness." After the war, poets not infrequently attributed quite the opposite qualities to the same plant: "it is a weed," "it is eradicated" (Kuryłowicz 2012). This clearly shows how arbitrarily the role of plants is determined and how it shifts over time, not to mention how fragile their safety is. The title of a nineteenth-century volume demonstrates that today the utilitarian history of various species is more transparent: Popular botany comprising the description of trees, shrubs and green plants both domestic and foreign, peculiar in their qualities and history, as well having use in industry, arts, crafts, household and farm (Pisulewski 1845; published in Polish). And yet the term "weed" does not feature in any botanical taxonomy, since the category is molded solely from the standpoint of and with respect to humans. The struggles of a gardener fighting weeds are also a metaphor of the fight with "social pests" and the Shoah, to which Zygmunt Bauman refers:

Whoever had a garden once knows that before flowers bloom and the shrubs they planted grow, a perfect garden is envisioned: where and what should be and how aesthetic harmony is to be achieved on that plot of land surrounded by a fence. The moment that ideal arrangement is there, all potential residents of the garden, all plants which were to take root there, have been rapidly divided into two categories: the useful plants and all other vegetation that was not intended, weeds in other words.... Well, being is not a trait peculiar to a plant. A weed is not a peculiar trait of a plant. It derives from how the gardener looks at it, deciding that it (i.e., the plant) does not tally with the pre-statutory horticultural norm. (Bagiński and Jóźwicki, n.d.)

Often enough, plants which may even be closely related to cultivated ones are considered weeds. In order to use flax effectively as a product, human has utterly wiped out the co-occurring species, such as flax dodder and flat-seeded false flax. Ludwik Hieronim Morstin had already made the prophetic warning: "I cannot drive the ploughshare into earth, for it will only mince the flowers with dust in the field, cut through bluebottles and the corncockle's abundant bloom, which shines akin to a dream. And said it is that woe betide the earth if it loses flowers, for flax alone will not make human garb" (Morstin 1909, 10-11).

Grzywnowicz shows over six decades of coexistence of plants with people, perceived as useful or vegetal "pests." The gardens, abandoned under duress, are spontaneously grown over by weeds, but they remain gardens thanks to species which in a singular fashion "remember" the coexistence with humans. At this point, 
one should recall assertions presuming plant intelligence. As Daniel Chamovitz wrote:

the question, should not be whether or not plants are intelligent-it will be ages before we all agree on what that term means; the question should be, 'Are plants aware?' and, in fact, they are. Plants are acutely aware of the world around them. They are aware of their visual environment; they differentiate between red, blue, far-red, and UV lights and respond accordingly. ... Plants know when they are being touched and can distinguish different touches. They are aware of gravity: they can change their shapes to ensure that shoots grow up and roots grow down. And plants are aware of their past: they remember past infections and the conditions they've weathered and then modify their current physiology based on these memories. (Chamovitz 2012, 157)

Numerous works of art and commemorations utilize plants as metaphors, yet it rarely happens that commemoration relies on the memory of plants themselves.

In Warsaw, plants were on the verge of having a memorial of their own. They would have been able to naturally commemorate a multicultural site: the bazaar known as Jarmark Europa, the phantom "city within a city," a hope for a better life for thousands of people from various parts of the world or a place where a life came to an end (if only to recall the death of Nigerian Maxwell Itoya, who was shot there by a Polish policeman). At the top of the bowl and between the rows of seats soon to be demolished stadium, Marek Ostrowski and a team of researchers found many plants whose presence in Warsaw was nothing short of astonishing. Gilles Clément refers to such places as "third landscapes" (n.d.); in order for such a wild site to be called a third landscape it has to emerge spontaneously, as opposed to being a trace of a garden once designed by a human. The most vivid popular example in cities are the surroundings of tracks and lines.

No one paid attention to the fact that right next to the bustling bazaar, new life came into being on the disused stands, and the stadium began to fill with new organisms. ... At first, the changes were insignificant, virtually imperceptible to an unskilled observer. A tiny piece of poplar fluff, borne by the wind, would land into a crevice in the cracked concrete, from which a several-centimeter-long seedling of poplar would germinate over the next few days. A bird perched there for a moment, leaving a black-and-white spot of droppings, which contained minute, one-seeded stones of black elder. The seeds, partly digested in the bird's alimentary tract, were additionally stimulated into germination. Someone from the bazaar spat out grape seeds over their shoulder. Having fallen on the stands, it grew after a few years into climbers running several meters in length. [...] As the vegetation proliferated on the stadium, microclimatic conditions at the site changed as well. Mass emergence of plants on the stands reduced thermic contrasts and promoted a milder climate. Gradually, a network of dependencies developed between the habitat (climate and edaphic conditions) and the species composition of animal and plant life. Subsequent developments may be forecast based on vegetal expansion observed so far. Had the stadium not undergone conversion, in several years' time its bowl would have been filled by a forest of trees, visible from afar as 
a green 'mop' swaying with the wind above its crown. Thus, with the contribution of plants a new, astonishing architectural form would have come into existence-a monument to the vitality of nature in places abandoned by humans. (Ostrowski, Sudnik-Wójcikowska, and Galera 2008, 98, 101)

A similar vision works well only in the utopian projects of ecological urban planning. 4 This kind of functional shift aimed at transforming a no longer needed stadium would also find justification in the futuristic Hotel Polonia. The Afterlife of Buildings, hatched by artists Nicolas Grospierre and Kobas Laksa as well as curators Grzegorz Piątek and Jarosław Trybuś, winner of the Golden Lion at the Architecture Biennale in Venice. In the real world, the influence of developers and the material value of urban space effectively hinder such solutions from ever being implemented.

In her subsequent project, Grzywnowicz reverses the vector and examines how people remember plants and how the latter become witnesses to history: Grün|Green consists in searching for plants that have been important for the people of Wrocław as well as their associated stories, thereby rendering a map of individual "green memorials." "The author is interested in the history and identity of the city as it is recorded in plants ... she is going to investigate the attitudes of inhabitants towards greenery in the city, focusing on trees in particular. It is the trees which are witnesses to history and represent links between Breslau and Wrocław; not infrequently, they are the backdrop to major events, collective and individual alike" (Wrocenter, n.d.). In any case, the story of Joanna Paśniewska demonstrates that the phenomenon is not limited to that region:

My grandmother ended up in Międzyrzecz 5 (in the present day Lubuskie Region) right after the war, coming from Płock, as her railwayman father received a new posting in the Recovered Territories. At the time you were already able to settle in former German houses, taking entire farms as your own. Grandma used to retell the story in quite a colorful fashion: she would often remember the soup left in plates on the table, a detail illustrating the panic in which Germans had fled. The mayor of the town, Herr Haak, acting upon instructions from above, kept the residents in an illusory idyll of safety, convinced that everything is under control until the very last day before the tanks of the Red Army reached the Miedzyrzecz area and everyone had to be immediately evacuated. When, after the war, my grandfather Henryk found his wife-returning from fiveyears' incarceration in Dachau (where he was sent as a teacher of mathematics during the Intelligenzaktion in spring 1940) - he was less than enchanted with having to live among

4 "In an ecological perspective, urban planning means a skill of building structures which sustain urban life and managing their development in accordance with the laws of nature and culture, as well as a science concerned with the fundamentals of rational performance of such tasks by various institutions of civil society" (Zuziak 2007, 9-20 $\mathrm{xx})$.

5 Previously German Meseritz. From 1942 to 1945 in the hospital in Obrawalde some 10,0oo people were killed as part of the Aktion $\mathrm{T}_{4}$; in the town and its surroundings there were also POW and forced labor camps. 
mementoes of German presence. The silver trays inscribed with Fraktur were found to be fit only for hens, while grandfather himself refused to eat plums and apples from trees that belonged to the former household. He would say that German blood ran in them. Grandma Hala tended to the garden with great tenderness, and long after grandfather had died, she would tell us tales of the garden's plants, recalling and commemoratingwithout a distinct reason-the German lineage of trees, shrubs, and flowers. This grandmother's account of the bi-national garden became a family fable. ${ }^{6}$

A strategy resembling the one in Grün and Weeds was adopted by Łukasz Surowiec in the 2012 project Berlin-Birkenau. The artist dug out young birches from the Birkenau area and planted them in school gardens and public spaces in Berlin. The young trees travel in the opposite direction of Jews deported from Berlin to the concentration camp. Surowiec intends to highlight the blending of remembering with the daily activity of tending to the plant, compelling one to rethink the role of recipients of commemoration.

Monuments, plaques, historical sites, preserved without change or reconstructed, located in particular spaces, as well as the recurring anniversary celebrations are important elements of the cityscape, to a large extent reflecting the state of collective memory and the mode in which continuity of identity is built. However, one must not overlook that cultural forms of commemoration are associated with historical policies pursued at the time. After the watershed of 1989, a number of commemorations were no more, some were widely disputed, and a few new ones emerged. At the same time the issues of counter-memory, post-memory, and the status of commemoration became material to work on for contemporary artists. John Bondar claims that public memory today is forged in the strife or dialogue of various social groups, representing a compromise between official and vernacular memory. ${ }^{7}$ Plants incorporated in the commemoration narratives endow them with a temporal and performative nature. Thus, memorials change their shape and continually yield new meanings. The apprehension surrounding the cultural role of plants may perhaps lie in the subconscious European association with paganism (in contrast to Far Eastern systems of belief), which was addressed by Matthew Hall (2011). The fear prevents us from entering into relationships with plants, abolishing the hardened dividing lines which delineate their and our domains. Consequently, such green monuments still tend to "happen" and elicit anxiety in the viewers-especially in their founders.

On the night, the $22^{\text {nd }}$ of April, 2016, unidentified individuals vandalized the Memorial to the Extermination of the Roma People in Borzęcin. It is located in a forest, far from human dwellings, and as such recalls the hundreds of sites in the woods where people had been executed. This aspect is analyzed by Roma Sendyka,

\footnotetext{
6 Joanna Paśniewska’s family reminiscence, delivered during Prof. Anna Zeidler-Janiszewska’s workshop Historical policies versus history and memory-selected case studies, is a commentary to this text.

7 See Bodnar (1992), Assmann (2013).
} 
who draws attention to the erstwhile markings of forest graves: "the flawed nonhuman tokens made of stones, litter and broken twigs, half-funereal, half-soulless ... should thus be considered as possibility of a monument', ambivalent and disquieting though it may be, but a monument nevertheless" (Sendyka 2017). The author of the design, Małgorzata Mirga-Tas, drew on the potential memory of the forest:

I decided to fashion the monument using larch wood. I found it to be an ideal material, as I did not wish the monument to flaunt gold lettering, marbles, granites and so on.... I thought that what had happened there left a mark on that place, and only trees can pass it on to a tree. The forest remembers and my initial impression was that they are a kind of silent witnesses. Now a little larger and older. Obviously, the monument is sure to change as years go by, begin to live its own life, the forest is certain to adopt it somehow and it will become a part of this place ... but this is how it should be; it is to be a part of the forest which remembers the crying, the dread, the fear the shooting, the faces. (Gancarz 2011, 268)

The process of the monument's merging into the forest was disrupted by a nationalistic act of vandalism. ${ }^{8}$ Integration of plant expression into memorial projects has never gained recognition in Poland, beginning with the most notorious and controversial design submitted in 1958 to an international competition for a memorial to the victims of fascism in Auschwitz-Birkenau: the concept was entitled The Road. It relied on Oskar Hansen's conception of Open Form according to which a monumental sculpture would be molded. Setting out from the premise that the entire area of the camp was a site of tragic experience, Hansen's team came forward with an idea to build a broad asphalt road running through it. Cutting the camp in two with a road and welding the main entrance gate shut would be a symbolic gesture of crossing out the crime committed there as something that must never happen again. The road would provide a background to individual acts of commemoration by those who visited the site: stones associated with the Jewish tradition, lights, or other mementoes left on its edges. The camp barracks stretching on either side would be left alone, yielding with time to slow entropy. The area of the camp, gradually growing over with forest, was to remind one of the time which had elapsed since the tragic events. Former prisoners could not bear the sight of Birkenau overgrown with chamomile and rejected the concept of The Road. Meanwhile, Ewa Domańska observes that even though organic remnants may mix with other elements of the ecosystem, the process does not degrade the humanity of the deceased, but validates their potential (biological) existence.

In the perspective of very long persistence, the spaces of the Holocaust, seen from an econecro standpoint, also become figures of a viable community and a symbiotic diaspora: an ecumene of varied life forms. (Domańska 2017, 34-61)

8 The monument was vandalized on April 22, 2016; the stele was knocked off of the concrete plinth, while the sculptures were chopped into pieces with an axe. 
However, the jury imposed a compromise, under which three shortlisted designs would be combined into one..$^{9}$ Oskar Hansen withdrew from the compromise, whose outcome may be seen today at the end of the tracks in Birkenau. Looking at the monument from the perspective of the present day, one readily sees that in aesthetic terms it belongs to a bygone era; now, it is virtually out of place, ill-suited (Pietrasik 2017).

Paradise, a project developed by Mirosław Duchowski's team for the Warsaw neighborhood of Szmulowizna, shared a similar fate. They conceived a memorial to Shmuel Jakubowicz (Joseph Samuel Sonnenberg), also known as Zbitkover, founder and owner of that part of the Praga district, in the form of an open, public orchard, whose fruits would be for everyone to enjoy, local inhabitants and tourists alike. After all, Gan Eden, the "garden of delights," was not only a symbol of the covenant between God and humanity, but also between God, humanity, and nature: "and the Lord God planted a garden in Eden, in the east; and there he put the man whom he had formed. Out of the ground the Lord God made to grow every tree that is pleasant to the sight and good for food, the tree of life also in the midst of the garden, and the tree of the knowledge of good and evil" (Gen. 2: 8-9). The welcoming retreat would encourage reflection on the extraordinary story of Henri Bergson's ancestor, make one think of the fates of pre-war Jewish residents of Szmulki, and the shape of Polish-Jewish dialogue (for which the idea of the garden of paradise-shared by all religions of the Book-provided a fitting metaphor). One may note at this point that, next to weeds, old orchards are another object of concern and conservation efforts. However, the interests of a developer aiming to build a gated estate on the premises of the former spirits manufactory prevailed: the idea to incorporate a public space into the development plan was rejected. We can thus return to Neil Smith's deliberations, which recall the history of debate taking place in the British forum for critical and radical geographers (crit-geog-forum.uk) relating to politics of gardening. Smith posed a question, why did an initial serious inquiry about the politics of gardening seem to unleash such pent-up political responses in a way that global events did not, even such serious ones as the famine in Sudan or the revolt in Indonesia (Smith 2000). Cities dominate in the world and, condensing life as they do, vividly expose the links between capital and local municipal authority. To describe the relationship, the urban geographer coins the notion of geobribe (Smith 2002). Gentrification investments and more modest, borough-range activities are channels for the flow of global capital and people. The plans of urban space reflect the relations of power and manifest

9 The person elected as chair of the jury in the competition for the International Memorial to the Victims of Fascism was Henry Moore, at the time considered one of the most eminent living sculptors. The event was remembered by means of an exhibition entitled Moore/Auschwitz, Tate Britain, London, May 10-June 13, 2010; curator: Ewa Toniak, arrangement: Małgorzata Szczęśniak, collaboration: Agata Pietrasik, Łukasz Kwietniewski. 
the most radical forms of oppression, exclusion, and inequality. City gardens and green areas are also a gentrification frontier under siege.

In this light, the installation by Grzywnowicz becomes a two-fold commemoration. Firstly, a deliberate one-a subtle poetic memorial to the displaced. Such an interpretation of the work is currently very important and relevant, ${ }^{10}$ because that chapter in history has been repressed from the official discourse of historical politics. ${ }^{11}$ Secondly, it is a symbolic monument of martyrdom of "green urban anarchists" or rather "true rhizomatic revolutionaries," in a way against the intentions of the artist. After all, how did we bid farewell to Weeds? In 2016 the artist handed her work over to the city of Warsaw. The meadow brought from the resettled locations was placed on the Kościuszko Wharf, near Lipowa street. It is to remain there for good, enriching the Cubryna Square. The artist signed an agreement with the municipal property boards, according to which the meadow was to be mowed once in autumn, so that the plants could bear seeds and scatter them. Whether by heedless haste or on purpose, municipal services mowed it barely a month after it was presented (it was determined who was responsible). They did it twice, just to be sure (Dłużewska 2016).

\section{Conclusions}

The garden has always been a cultural text, and it is not without a reason that it lends its very name to volumes of poetry (such as The Garden of Epigrams by Wacław Potocki). The phenomenon of the household garden, etymologically an "enclosure" (cut off from the wilderness), is intrinsically similar to a zoological garden. Both animals and plants live in these peculiar spaces under the very special care of humans. In both cases, exotic and rare species are preferred, while the common and "meagre" ones are excluded; in these gardens the life of plants and animals is subordinated to eugenic projects. In either case, non-human subjects are anthropomorphized on the one hand and serve human entertainment on the other. The surroundings of the non-human beings are shaped by the human hand and isolated from the impact of nature (cages, pavilions, ${ }^{12}$ pens, lawns, flowerbeds, and pergolas). These two garden models were subjected to a test in the course of the dramatic historical events of the twentieth century.

10 In 2017, state authorities refused to participate in the commemoration of those events, which had been prepared by communities and organizations of Ukrainians and Lemkos.

11 Weeds was a cause for dissatisfaction among nationalists; see e.g. the unsigned article Sztuka zydowska - CHWASTY na śmietnik, Wierni Polsce Suwerennej, https://wiernipolsce1.wordpress.com/2016/o8/o4/sztuka-zydowska-chwastyna-smietnik, August 4, 2016.

12 New Architecture of the London Zoo, a 1938 film by László Moholy-Nagy splendidly illustrates the relationship between modernist architecture and the animal world; apparently, animal behavior would change as a result of architectural designs and devices implemented by modernists. 
In 2012, Éric Baratay called for the introduction of another historical counternarrative, in which the perspectives of animals would be taken into account. As Baratay wrote, the animal facet of history is likewise epic, turbulent, laden with contrasts, often bloody, at times serene and not infrequently comical. It has been written down with flesh and blood, with sensations and emotions, with fear, pain and pleasure, with the violence suffered and complicity shared. Its direct influence on the human is so extensive that human history is shaped thereby to an everincreasing degree. Hence it is by no means anecdotal or secondary, and thoroughly deserves attention of historians who set a great store by history in all its complexity and diversity. One should liberate history from anthropocentric vision, take note of human companions, other living beings - animals, go over to their side, see things from their standpoint, reversing the questions, searching for more eloquent documents, rereading those we have differently, thus decentralising the narrative. (Baratay 2014)

Works originating in the milieu of animal studies or anthropozoology have very promptly addressed that gap and proceed to fill it, as they arduously seek to separate human history of animals from animal history.

Things stand somewhat differently with plant history. In 2009, Eduardo Kac's Edunia was presented for the first time (Kac 2010, Bakke 2011). That art project embarked on the "overlooked" kinship between humans and plants on the molecular level. Still, questions concerning the impact of plants on the history of human beings and the ramifications of historical events they are subject to are only now becoming a challenge to contemporary ethnobotany. This may be the reason why successive species of plants that humanity considers useless disappear at a frightening pace in the wake of current political and economic processes. Perhaps the hope of plants lies solely with the superweeds, ${ }^{13}$ vegetal superheroes which had already been predicted in the theory of evolution?

\section{References:}

Assmann, Aleida. 2010. "Canon and Archive. In A companion to cultural memory studies", edited by Astrid Erll, Ansgar Nünning, 97-108. Berlin: de Gruyter,

Assmann, Aleida. 2013. "Pamięć miejsc — autentyzm i upamiętnianie" ["The Memory of Place_- Authenticity and Commemoration"]. Translated by Justyna Górny. In Między historią a pamięcią. Antologia [Between History and Memory: Anthology], edited by Magdalena Saryusz-Wolska, 168_89. Warsaw: WUW

Bagiński, Arek and Andrzej Jóźwicki. n.d. O nowoczesności i zagładzie [On Modernity and Extermination]. http://industrialart.eu/teksty/wywiad-nowoczesnosc-i-zaglada. Accessed April 14, 2017

13 Plants which, due to spontaneous mutations or crossbreeding with GMO species, have become resistant to herbicides. 
Bakke, Monika. 2011. "Postnaturalna historia Edunii" ["A Post-Natural History of Edunia"]. Kultura Współczesna 1: $116-24$.

Baratay, Éric. 2012. "Le point de vue animal. Une autre version de I'histoire", Paris: Seuil.

Bodnar, John. 1992. Remaking America: Public Memory, Commemoration, and Patriotism in the Twentieth Century. Princeton: Princeton University Press.

Burnett, Frances Hodgson. 1911. The Secret Garden. New York: Frederick A. Stokes Co.

Chamovitz, Daniel. 2012. What a Plant Knows: A Field Guide To The Senses Of Your Garden - And Beyond. New York: New Farrar, Straus and Giroux.

Clément, Gilles. n.d. The Third Landscape. http://www.gillesclement.com/art-454-tit-The-Third-Landscape. Accessed April 14, 2017.

Dłużewska, Emilia. 2016. "Warszawa. Instalacja artystyczna "Chwasty" skoszona przez kosiarkę" ["Warsaw. Artistic Installation "Weeds" Mowed]. Gazeta Wyborcza, August 2.

Domańska, Ewa. 2010. "Jakiej metodologii potrzebuje współczesna humanistyka?" ["What Kind of Methodology do the Contemporary Humanities Need?"]. Teksty Drugie 1/2: 45-55.

Domańska, Ewa. 2017. "Przestrzenie Zagłady w perspektywie ekologiczno-nekrologicznej" ["Post-Holocaust Spaces in an Ecological-Necrological Perspective"]. Teksty Drugie 2: 34-61.

Gancarz, Natalia. 2011. "Pierwszy figuralny Pomnik Pamięci o Zagładzie Romów" ["The First Figural Memorial to the Roma Victims of the Genocide"]. Studia Romologica 4: 267-70.

Gieba, Kamila. 2017. "Dyslokacja przestrzeni, dysfunkcja tożsamości. Elementy kontr-dyskursu w polskiej literaturze migracyjnej (1945-1989)" ["Dislocation of Space, Dysfunction of Identity: Elements of Counter-Discourse in Polish Migrant Literature (1945-1989)"]. In Migracyjna pamięć, wspólnota, tożsamość [Migrant Memory, Community, Identity], edited by Ryszard Nycz, Tomasz Sapota, Roma Sendyka, 206_-24. Warsaw: Wydawnictwo Instytut Badań Literackich PAN.

Grzywnowicz, Karolina. n.d. http://chwasty.com/o-projekcie/. Accessed April 14, 2017.

Hall, Matthew. 2011. Plants as Persons. A Philosophical Botany. New York: State University of New York Press.

Jeśman, Joanna. 2015. Żywa Sztuka. Wielowymiarowość bioartu w kontekście posthumanistycznym [Living Art: Multidimensionality of Bioart in a Post-Humanist Context]. Warsaw: Wydawnictwo Akademickie Sedno.

Kac, Eduardo. 2010. "Bio Art: Od Genesis do Natural History of Enigma" ["Bio Art: From Genesis to the Natural History of Enigma"]. Translated by Mariola Sułkowska-Janowska. Folia Philosophica 28: $13-37$.

Kuryłowicz, Beata. 2012. Semantyka nazw kwiatów w poezji Młodej Polski [Semantics of Plant Names in Young Poland Poetry]. Białystok: Wydawnictwo Uniwersytetu w Białymstoku.

Leśmian, Bolesław. 1920. Łąka [Meadow]. Kraków: J. Mortkowicz.

Marx, Karl. 1932. Capital: A Critique of Political Economy. Translated by Samuel Moore and Edward Aveling, New York: Random House Inc.

Morstin, Ludwik Hieronim. 1909. Psalm ziemi, Chwasty kwitnące na rodzajnym polu. Poezye [Earth Psalm: Weeds in Flower on a Fertile Field; Poems]. Kraków.

Mościcki, Paweł. n.d. http://chwasty.com. Accessed April 14, 2017. 


\section{Monika Weychert}

Nijakowski, Lech M. 2006. Domeny symboliczne. Konflikty narodowe i etniczne w wymiarze symbolicznym [Symbolic Domains: National and Ethnic Conflicts in the Symbolic Dimension]. Warsaw: Wydawnictwo Naukowe Scholar.

Ostrowski, Marek, Barbara Sudnik-Wójcikowska, and Halina Galera. 2008. "I oczom odkrywców ukazała się zielona wyspa... Badanie botaniczne na Stadionie" ["And the Discoverers' Eyes Saw a Green Island... Botanic Research at the Stadium"]. In Stadion X. Miejsce, którego nie było. Reader [Stadium X: A Place that Never Was; A reader], edited by Joanna Warsza, 98-101. Warsaw: Korporacja Halart, Bęc Zmiana.

Pietrasik, Agata. 2010. Przekraczając monumentalność — projekty pomnika w Birkenau. [Beyond Monumentality - projects for the Birkenau Monument]. http://archiwum-obieg.u-jazdowski.pl/ teksty/17949,29.06.2010. Accessed April 17, 2017.

Pisulewski, Szymon. 1845. Botanika popularna obejmująca opisanie drzew, krzewów i roślin zielonych tak krajowych, jak i zagranicznych, szczególnych swemi własnościami i history, tudzież mających zastosowanie w przemyśle, sztukach, rzemiosłach, gospodarstwie domowem i wiejskiem [Popular Botany Comprising the Description of Trees, Shrubs and Green Plants Both Domestic and Foreign Peculiar in Their Qualities and History, as well Having Use in Industry, Arts, Crafts, Household and Farm]. Warsaw.

Sendyka, Roma. 2017. "Nie-miejsca pamięci i ich nie-ludzkie pomniki" ["Non-Places of Memory and Their Non-Human Monuments"]. Teksty Drugie 2: 86-109.

Smith, Neil. 2002. "New Globalism, New Urbanism: Gentrification as Global Urban Strategy." Antipode 34: $427-50$.

Smith, Neil. 2008. Uneven Development: Nature, Capital and the Production of Space. Athens, Georgia: University of Georgia Press.

Smith, Neil. 2000. "What happened to class?" Environment and Planning A 32: 1011—32.

Springer, Filip. 2011. Miedzianka. Historia znikania [Miedzianka: A History of Disappearing]. Wołowiec: Wydawnictwo Czarne.

Szelburg-Zarembina, Ewa. 1972. "Ogród króla Marcina" ["King Martin's Garden"]. In Królestwo Bajki [Fairy tale kingdom], 231—336. Warsaw: Nasza Księgarnia.

Wrocenter. n.d. http://grun.wrocenter.pl/o-projekcie/. Accessed April 14, 2017.

Zuziak, Zbigniew K. 2007. "Ekologiczne definiowanie urbanistyki" ["Ecological Approach to Town Planning"]. Czasopismo Techniczne z. 7-A: 9-20. 